\begin{tabular}{|l|l}
\hline & JTMT \\
Jurnal Tadris Matematika \\
Vol 1 No 22020 \\
ISSN (print) : $2745-956 X$ \\
ISSN (online) : $2745-9551$ \\
Homepage $: \underline{\text { http://journal.iaimsinjai.ac.id/index.php/Jtm }}$ \\
\hline
\end{tabular}

\title{
PERBANDINGAN HASIL BELAJAR MATEMATIKA DENGAN MENGGUNAKAN MODEL NUMBER HEAD TOGETHER (NHT) DAN THINK PAIR SHARE (TPS) BERBASIS MEDIA WHATSAPP
}

\author{
Annisa Rahayu', Ernawati ${ }^{2}$, Rizqi Ashari Rahim ${ }^{3}$ \\ ${ }^{1}$ Universitas Muslim Maros,maros \\ ${ }^{2}$ Universitas Muslim Maros,maros \\ ${ }^{2}$ Universitas Muslim Maros,maros \\ E-mail:@annisarahayu2809@gmail.com.Telp.0895804681851
}

\begin{abstract}
Abstrak
Penelitian ini merupakan penelitian Quasi Experimental yang bertujuan untuk mengetahui perbedaan hasil belajar siswa dari penerapan model pembelajaran kooperatif tipe Number Head Together (NHT) dan Think Pair Share (TPS) pada Siswa Kelas VII SMP Negeri 11 Maros Baru. Metode penelitian ini adalah penelitian kuantitatif dengan contrablanced design, dimana terdapat dua kelompok eksperimen. Number Head Together sebagai kelompok eksperimen I dan Think Pair Share sebagai keompok eksperimen II.. Sampel dalam penelitian ini adalah siswa kelas VII C sebagai eksperimen I dan kelas VII B sebagi eksperimen II. Instrumen penelitian yang digunakan adalah tes hasil belajar matematika berupa Essai yang telah divalidasi. Teknik Analisis data yang digunakan adalah teknik statistik deskriptif dan teknik statistik inferensial. Berdasarkan hasil analisis data di simpulkan bahwa hasil belajar siswa yang diajar dengan model pembelajaran kooperatif tipe Number Head Together (NHT) pada kelas Eksperimen I, nilai rata-ratanya 80.30 dan standar deviasi 8.354 sedangkan siswa yang diajar dengan model pembelajaran kooperatif tipe Think Pair Share (TPS) pada kelas Eksperimen II nilai rata-ratanya 71.50 dan standar deviasi 10.014. Hasil uji-t diperoleh nilai sig sebesar $0.047<0.05$ maka dapat disimpulkan bahwa analisis hipotesis Ho ditolak dan $\mathrm{H}_{1}$ diterima yaitu terdapat perbedaan hasil belajar matematika siswa antara kelas yang diajar model pembelajaran kooperatif tipe Number Head Together (NHT) dengan kelas yang dajar model pembelajaran tipe Think Pair Share (TPS) kelas VII SMP Negeri 11 Maros Baru.
\end{abstract}

Kata Kunci: perbandingan hasil belajar matematika, number head togerher, think pair share

\begin{abstract}
This research is a Quasi Experimental study that aims to determine differences in student learning outcomes from the application of cooperative learning models of Number Head Together (NHT) and Think Pair Share (TPS) in Class VII Students of SMP Negeri 11 Maros Baru. This research method is quantitative research with contrablanced design, where there are two experimental groups. Number Head Together as experimental group I and Think Pair Share as experimental group II. The sample in this study were students of class VII C as experiment I and class VII B as experiment II. The research instrument used was a mathematics learning achievement test in the form of a validated Essay. The data analysis technique used is descriptive statistical techniques and inferential statistical techniques. Based on the results of data analysis using SPSS 24, which was taught with the cooperative learning model type Number Head Together (NHT) in Experiment I class with an average value $=80.30$ and standard deviation $=8.335$ while students who were taught with the cooperative learning model Think type Pair Share (TPS) in Experiment II class with an average value $=71.50$ and standard deviation $=$
\end{abstract}


10.014. Based on the results of calculations using SPSS 24 t-test obtained a sig value of $0.047<0.05$, it can be concluded that the analysis of the hypothesis $H o$ is rejected and $H_{1}$ is accepted, this means that there are differences in students' mathematics learning outcomes between classes using the Number Head Together cooperative learning model (NHT) and classes that use the Think Pair Share (TPS) type VII class of SMP Negeri 11 Maros Baru

Keywords: comparison of mathematics learning outcomes, Numbered Head Together, Think Pair Share

\section{Pendahuluan}

Pendidikan merupakan kebutuhan yang sangat penting, dengan adanya pendidikan seseorang dapat menuntut ilmu, dengan ilmu yang telah didapatkan maka dapat diterapkan dalam kehidupan sehari-hari. Pendidikan yang layak menjadi wajib untuk dimiliki agar terwujud generasi berkualitas yang mampu bersaing dilingkungan maupun di seluruh dunia. "Pendidikan merupakan kebutuhan yang sangat penting bagi manusia. Seseorang yang memiliki pendidikan yang baik akan mampu bersaing di dunia luar dan mampu menghadapi setiap perubahan menuju arah yang lebih baik" (Sitti Rohani, 2017)

Peran pendidikan menunjukkan keseriusan untuk menciptakan pribadi yang unggul dan mampu menyelesaikan permasalahan yang ditemuinya. Sekolah menjadi sarana dalam memberikan pengetahuan yang dibutuhkan. Berbagai metode atau pendekatan dilakukan untuk menunjang siswa lebih paham dalam memahami materi. Hal ini selaras dengan pernyataan Soyomukti ((Hariyanti, 2019)) menyatakan bahwa Pendidikan dalam arti sekolah dibutuhkan berbagai macam metode pengajaran yang dipilih agar efektif dalam membentuk kemampuan kognitif, afektif, dan psikomotorik siswa. Berbagai pendekatan disiplin ilmu pun digunakan untuk membuat pengajaran mendapatkan manajemen yang tepatguna. Dalam proses pembelajaran, kegiatan belajar mengajar merupakan kegiatan yang paling pokok, karena berhasil tidaknya pencapaian tujuan pendidikan banyak bergantung kepada bagaimana proses belajar mengajar dirancang dan dijalankan secara professional.(Syarifuddin, 2020)

Menurut Yeni (dalam (Gasali \& Nasir, 2019)) Pembelajaran matematika saat ini dianggap pelajaran yang sulit oleh sebagian peserta didik karena abstrak, tidak saja oleh siswa tingkat sekolah dasar bahkan hingga mahasiswa di perguruan tinggi. Matematika juga sebagai salah satu sarana berpikir ilmiah yang sangat diperlukan untuk menumbuh kembangkan kemampuan berpikir logis, sistematis, dan kritis dalam diri peseta didik. Nilai matematika memegang peranan penting dalam menentukan syarat kelulusan siswa, karena matematika merupakan salah satu mata pelajaran wajib yang diujikan pada ujian nasional". Salah satu materi pendidikan yang perlu untuk mendapat perhatian adalah pelajaran matematika. Matematika merupakan salah satu bidang studi yang amat penting dalam kehidupan sehari-hari. Hampir seluruh aktivitas kehidupan kita bersinggungan dengan matematika, sehingga perlu adanya penguasaan yang tepat terhadap bidang studi ini ((Rahmayanti, 2017)).

Jadi, matematika adalah ilmu yang memiliki peran penting dalam penggunaannya atau aplikasi di kehidupan sehari-hari. Sehingga hal ini menjadi salah satu pertimbangan dalam pelaksanaan pembelajaran yang mampu memberikan pemahaman pada siswa.

Dari hasil observasi awal di SMP Negeri 11 Maros Baru proses pembelajaran yang dilakukan masih menggunakan pembelajaran langsung dan hasil belajar yang diperoleh siswa rendah (kurang). Hal itu dapat dilihat dari nilai ulangan harian yang kurang dari standar KKM oleh sebagian besar siswa. Sehingga dapat disimpulkan pembelajaran sangat berpengaruh bagi peserta didik. Begitu pula dengan pembelajaran langsung (konvensional). Guru hanya menjelaskan dengan metode ceramah berharap siswa datang, duduk, diam memerhatikan dan mampu mengerjakan soal secara individu kemudian mendapat hasil belajar matematika yang memuaskan. Sehingga tanpa sadar guru tidak memberikan peluang siswa untuk berkreasi dan mencoba menemukan jawaban secara bersama-sama. 


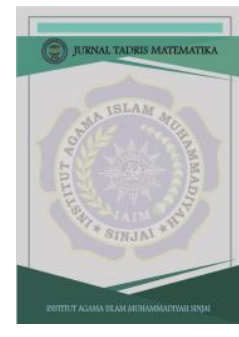

JTMT

Jurnal Tadris Matematika

Vol 1 No 22020

ISSN (print) : 2745-956X

ISSN (online) : 2745-9551

Homepage : http://journal.iaimsinjai.ac.id/index.php/Jtm

Sehingga guru harus memiliki model pembelajaran yang tidak biasa seperti pembelajaran konvensional yang terus diterapkan dalam proses pembelajaran.

Hal ini selaras dengan pernyataan ((Ernawati \& Lestari, 2020)) bahwa meskipun dalam penerapan pembelajaran matematika guru sudah menggunakan metode yang beragam, antara lain ceramah, latihan, dan diskusi. Namun metode tersebut belum dikembangkan secara optimal sehingga hasil belajar siswa belum maksimal. Hal tersebut ditunjukkan oleh metode pembelajaran yang digunakan membuat peran guru yang lebih dominan sehingga siswa belum semua terlihat aktif dalam proses pembelajaran. Guru lebih banyak menyampaikan materi dengan metode ceramah, kemudian siswa diberikan soal latihan. Hal tersebut menyebabkan proses pembelajaran belum maksimal dalam memberikan kesempatan kepada siswa untuk berpikir kritis dan bertindak kreatif.

Upaya untuk mengatasi kesulitan dalam pemberian model tersebut guru harus mengambil metode pembelajaran yang membuat siswa tidak berpangku tangan dan menunggu jawaban yang diberikan oleh guru. Yakni model pembelajaran kooperatif tipe Number Head Together (NHT) dan Think Pair Share (TPS).

Model pembelajaran kooperatif tipe Number Head Together (NHT) merupakan model pembelajaran yang pada dasarnya menciptakan suasana kelas yang baru dan lebih mengunggulkan pemikiran peserta didik dalam bekerjasama menemukan sebuah jawaban, menyatukan pendapat terhadap jawaban pertanyaan yang tengah dihadapi sehingga mampu menyimpulkan hasil akhir secara bersama-sama dengan teman kelompoknya. Model pembelajaran kooperatif tipe Think Pair Share (TPS) merupakan model pembelajaran yang menuntut siswa untuk berpikir dan menemukan jawaban secara berpasangan.

Menurut Rohani (2015) Model pembelajaran kooperatif tipe NHT dan TPS memiliki perbedaan yaitu pada model pembelajaran kooperatif tipe NHT siswa terlebih dahulu diberi kesempatan untuk berdiskusi dengan kelompok yang telah dibentuk, kemudian anggota kelompok yang dipanggil nomornya mempresentasikan hasil yang diskusi kelompoknya tanpa bantuan dari anggota kelompok lainya dan pembagian setiap kelompok terdiri dari 3 sampai 5 orang. Sedangkan pada model pembelajaran kooperatif tipe TPS siswa terlebih dahulu diberi kesempatan untuk berpikir secara individu, kemudian siswa berdiskusi dengan pasangannya lalu mempresentasikan di depan kelas, dan anggota kelompok yang dibentuk hanya terdiri dari 2 orang atau berpasangan. Sehingga dapat disimpulkan metode pembelajaran kooperatif tipe Number Head Together (NHT) merupakan pembelajaran berkelompok. Sedangkan metode pembelajaran kooperatif tipe Think Pair Share (TPS) merupakan pembelajaran berpasangan.

Media Whatsapp adalah salah satu media atau alat yang digunakan untuk nmemudahkan sesorang dalam berkomunikasi. Whatsapp memiliki dampak besar dalam menunjang pembelajaran.

Merebaknya pandemi covid-19 di Indonesia bahkan diseluruh dunia menjadi perhatian yang serius. Covid-19 adalah virus yang menyerang sistem pernapasan manusia dan tidak bisa dilihat dengan kasat mata. Hal itu membuat seluruh aktifitas dihentikan termasuk aktifitas proses belajar mengajar secara tatap muka. Upaya itu dilakukan agar menghentikan seluruh aktifitas yang bisa mencegah penyebaran covid-19 dan menjadi alasan utama dilakukan pembelajaran secara daring. Salah satu penggunaan media yang dilakukan adalah dengan media whatsapp. Kelebihan dari media whatsapp adalah kouta internet yang lebih hemat dipakai dalam penggunaan mengirim pesan, foto (gambar), pesan suara maupun vidio call. Namun, kekurangan dalam penggunaan aplikasi whatsapp adalah penggunaan pada saat video call tidak bisa memuat lebih banyak orang.

Dalam penelitian ini, saya ingin membandingkan model pembelajaran yang baik untuk siswa saat ini apakah ada perbedaan hasil belajar ketika menggunakan dua model yang berbeda pada kelas yang berbeda. Sehingga dalam penelitian ini saya mengambil judul proposal Perbandingan Hasil Belajar Matematika dengan Menggunakan Model Pembelajaran Kooperatif Tipe Number Head Together (NHT) dan Think Pair Share (TPS) Berbasis Media Whatsapp pada Siswa Kelas VII SMP Negeri 11 Maros Baru. 


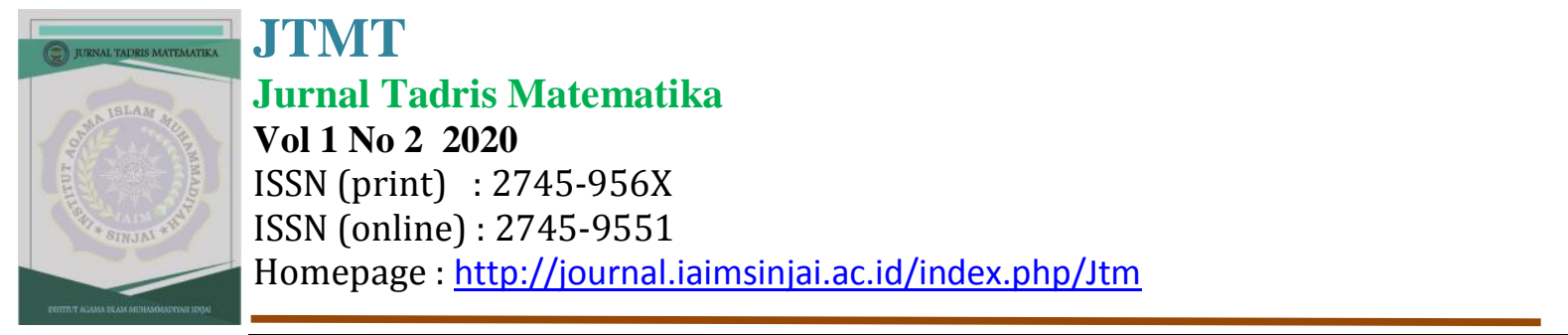

\section{Metode}

Jenis Penelitian ini adalah penelitian Quasi Experimental atau biasa disebut eksperimen semu. Penelitian ini melibatkan dua kelompok, yaitu satu kelompok sebagai kelompok eksperimen I dan eksperimen II.

Menurut (Susilo, 2013) jika semua kelompok eksperimen diberikan perlakuan maka desain penelitian yang harus digunakan adalah Counterbalance Design, karena tidak ada kelompok kontrol. Sehingga desain penelitian ini adalah Conterbalanced Design. Dalam desain ini terdapat dua kelompok, yaitu Number Head Together sebagai kelompok eksperimen I dan Think Pair Share sebagai eksperimen II. Dengan desain sebagai berikut:

Tabel 1. Conterbalanced Design

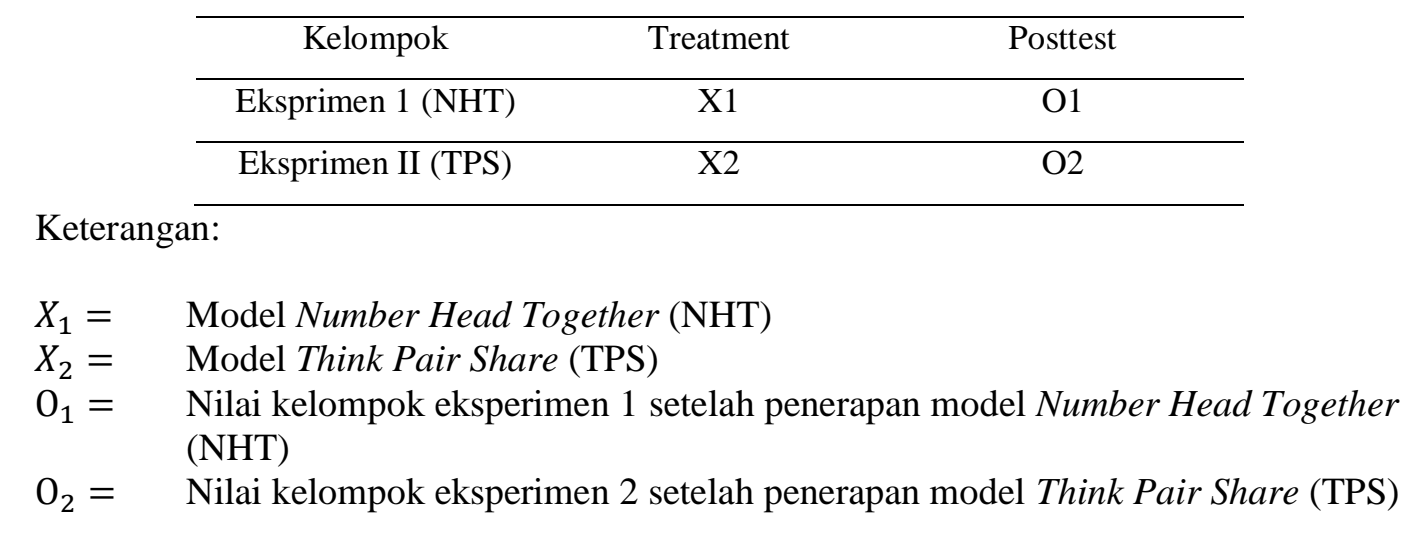

\section{Hasil dan Pembahasan}

Hasil Penelitian ini merupakan jawaban dari rumusan masalah yang telah ditetapkan sebelumnya yang dapat menguatkan sebuah hipotesis atau jawaban sementara.

Sebelum diberikan tes hasil belajar yaitu posttest, siswa terlebih dahulu diajar dengan menggunakan dua model pembelajaran yang berbeda. Kelas VII C menggunakan model pembelajaran kooperatif tipe Number Head Together (NHT) dan VII B menggunakan model pembelajaran kooperatif tipe Think Pair Share (TPS). Berdasarkan hasil penelitian yang telah dilakukan di SMP Negeri 11 Maros Baru diperoleh data sebagai berikut:

Tabel 2. Nilai Statistik Deskriptif

\begin{tabular}{ccc}
\hline & Kelas Eskprimen I & Kelas Eksprimen II \\
\hline $\mathrm{N}$ & 10 & 10 \\
Range & 30 & 30 \\
Minimum & 60 & 65 \\
Maximun & 90 & 95 \\
Mean & 71.50 & 80.30 \\
Std. Deviasi & 10.014 & 8.354 \\
\hline \multicolumn{2}{c}{ (Sumber: Analisis data dengan SPSS versi 24, 2020) }
\end{tabular}

Berdasarkan tabel 2 dapat diketahui bahwa posttest pada kelas eksperimen I yang menggunakan model pembelajaran Number Head Together (NHT) diperoleh nilai terendah adalah 65, nilai tertinggi adalah 95 dan nilai rata-rata adalah 80.30 dengan standar deviasinya adalah 8.354. Sedangkan pada kelas Eksperimen II yang menggunakan model pembelajaran Think Pair Share (TPS) diperoleh nilai terendah adalah 60, nilai tertinggi adalah 90 dan nilai rata-rata adalah 71.50 dengan standar deviasinya adalah 10.014 . 


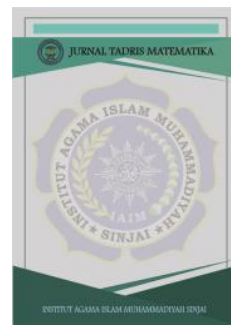

JTMT

Jurnal Tadris Matematika

Vol 1 No 22020

ISSN (print) : 2745-956X

ISSN (online) : 2745-9551

Homepage : http://journal.iaimsinjai.ac.id/index.php/Jtm

\begin{tabular}{llc|c|c|c|c|c}
\hline \multicolumn{7}{c}{ Tabel 3 Uji Normalitas } \\
\hline \multirow{2}{*}{ Kelompok } & \multicolumn{3}{c}{ Kolmogorov-Smirnov ${ }^{\mathrm{a}}$} & \multicolumn{4}{c}{ Shapiro-Wilk } \\
\cline { 2 - 9 } & Kelompok Eks 1 & .214 & 10 & $.200^{*}$ & .958 & 10 & .767 \\
\hline \multirow{2}{*}{ Nilai } & Statistic & Df & Sig. & Statistic & Df & Sig. \\
\cline { 2 - 9 } & Kelompok Eks 2 & .175 & 10 & $.200^{*}$ & .912 & 10 & .296 \\
\hline
\end{tabular}

Berdasarkan tabel 4.2, uji Normalitas dengan menggunakan uji Shaporo-Wilk diperoleh nilai signifikansi lebih besar dari 0.05. Eksperimen I (Number Head Together) diperoleh nilai signifikansi 0.767. Dan Nilai signifikansi 0.296 untuk Eksperimen II (Think Pair Share). Sehingga dapat disimpulkan bahwa data berdistribusi Normal.

Tabel 4. Uji Homogenitas

\begin{tabular}{lcc|l|l|l}
\hline \multicolumn{7}{c}{ Uji Homogenitas } \\
\hline & $\begin{array}{l}\text { Levene } \\
\text { Statistic }\end{array}$ & df1 & df2 & Sig. \\
\hline Hasil Belajar Siswa & Based on Mean & .605 & 1 & 18 & .447 \\
\hline
\end{tabular}

Berdasarkan tabel 4 diketahui nilai (sig) based on mean adalah $0.447>0.05$ maka dapat disimpulkan variasi data Eksperimen I dan Eksperimen II sama atau data homogen.

Tabel 5. Tabel Uji Hipotesis

Sig (2-tailed)
Hasil Belajar Siswa

Setelah melakukan uji prasyarat maka dilakukan uji hipotesis. Berdasarkan tabel 5. Uji hipotesis menggunakan uji-t independen dilakukan untuk menegetahui apakah ada tidaknya perbedaan rata-rata siswa kelas VII C dan VII B setelah dilakukan model pembelajaran yang berbeda pada kelas yang berbeda dan jika sig. (2-tailed) $<0.05$ maka Ho ditolak atau terdapat pebedaan ratarata siswa. Setelah dilakukan uji hipotesis dengan SPSS 24 dapat diketahui bahwa ada perbedaan ratarata hasil belajar matematika siswa yang diterapkan model pembelajaran kooperatif tipe Number Head Together (NHT) dan Think Pair Share (TPS) pada kelas VII SMP Negeri 11 Maros Baru. Hal itu dapat diketahui dari nilai sig. (2-tailed) $0.047<0.05$. Adapun nilai rata-rata model NHT adalah 80,30 dengan nilai terendah adalah 65, nilai tertinggi adalah 95 dan standar deviasi adalah 8.354. Sedangkan nilai rata-rata TPS adalah 71.50 dengan nilai terendah adalah 60, nilai tertinggi adalah 90 dan standar deviasi adalah 10.014. Standar deviasi model pembelajaran Number Head Together (NHT) lebih rendah dibandingkan standar deviasi model pembelajaran Think Pair Share (TPS) hal itu menandakan bahwa nilai standar deviasi Number Head Together (NHT) lebih baik dari pada Think Pair Share (TPS) karena semakin rendah nilai standar deviasi suatu data maka nilai penyebaran data semakin mendekati rata-rata. Jika nilai standar deviasi suatu data mendekati rata-rata, maka penyebaran nilai dan kemampuan yang dimiliki siswa hampir sama.

Perbedaan rata-rata siswa dikarenakan model pembelajaran Number Head Together (NHT) dan Think Pair Share (TPS) memiliki tahap pembelajaran yang berbeda dan dipengaruhi juga dengan jumlah orang yang ada di kelompoknya. Hal itu dapat terlihat dari tahap Number Head Together (NHT) merupakan pembelajaran berkelompok yang mengharuskan berdiskusi terlebih dahulu dengan teman kelompoknya dalam menyelesaikan tugas yang diberikan. Karena setiap kelompok yang terdiri dari 5 orang membuat diskusi aktif karena siswa yang lebih bisa dapat mengajari siswa yang belum bisa. Sedangkan tahap Think Pair Share (TPS) merupakan pembelajaran berpasangan yang mengharuskan berfikir sendiri terlebih dahulu sebelum berdiskusi dengan pasangannya dan karena jumlah kelompoknya hanya dua sehingga ide yang muncul hanya sedikit. Hal ini diperkuat dengan 


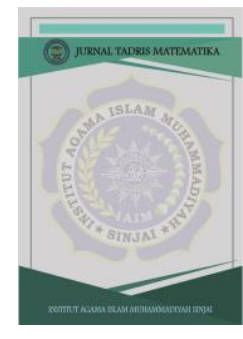

JTMT

Jurnal Tadris Matematika

Vol 1 No 22020

ISSN (print) : 2745-956X

ISSN (online) : 2745-9551

Homepage : http://journal.iaimsinjai.ac.id/index.php/Jtm

hasil penelitian sebeumnya yang dilakukan oleh Rahmayanti (2017) bahwa penerapan model pembelajaran kooperatif tipe Number Head Together (NHT) dapat memberikan hasil yang lebih baik dibandingkan dengan penerapan model pembelajaran kooperatif tipe Think Pair Share (TPS). Hal ini karena pada model pembelajaran kooperatif tipe Number Head Together (NHT) melibatkan lebih banyak siswa yang terlibat dalam menelaah materi dan banyak wawasan yang muncul, serta pada model pembelajaran kooperatif tipe Number Head Together (NHT) lebih mudah mengontrol kegiatan kelompok, karena kelompok yang dibentuk tidak banyak sedangkan pada model pembelajaran kooperatif tipe Think Pair Share (TPS) dapat terbentuk kelompok yang banyak karena kelompok dibentuk secara berpasangan.

Adapun kekurangan dalam penelitian ini adalah Penelitian dilakukan secara daring. Merebaknya pandemi covid-19 di Indonesia bahkan di seluruh dunia menjadi alasan utama dilakukan pembelajaran daring. Sehingga sekolah terhenti dan beralih ke pembelajaran daring atau lebih tepatnya dengan menggunakan bantuan aplikasi media Whatsapp. Situasi dan kondisi tidak memungkinkan untuk melakukan penelitian dengan pembelajaran secara langsung atau tatap muka dengan siswa. Setelah segala upaya yang dilakukan untuk berkoordinasi dengan kepala sekolah dan guru pengampu mengenai penelitian yang akan dilakukan di kelas VIIC dan VIIB SMP Negeri 11 Maros Baru maka sekolah memutuskan untuk memberikan kesempatan untuk melakukan penelitian. Pembelajaran daring dalam penelitian ini menggunakan bantuan aplikasi Whatsapp karena kondisi siswa yang tidak memungkinkan menggunakan aplikasi lain dengan penggunaan kuota yang lebih mahal. Kemudian jumlah sampel penelitian yang terbatas. Kondisi siswa yang berbeda-beda menjadi salah satu alasan sampel dalam penelitian ini terbatas. Kondisi itu meliputi: sebagian besar siswa yang tidak memiliki Handpone dan siswa yang tidak aktif karena jaringan dan keterbatasan kuota. Sehingga sampel dalam penelitian ini hanya berjumlah 20 orang dari dua kelas yang dijadikan sampel.

Adapun kelebihan dalam penelitian ini adalah hasil observasi keterlaksanaan pembelajaran yang dilakukan selama penelitian berlangsung pada dua kelas yang berbeda terlaksana dengan baik dengan persentase $100 \%$. Pembelajaran daring memberikan kesan yang berbeda yang membuat siswa dan guru lebih fokus akan jadwal yang diberikan. Sehingga siswa lebih menghargai waktu belajar yang telah disepakati bersama.

\section{Simpulan}

Berdasarkan hasil penelitian maka ditarik kesimpulan yiaitu hasil Belajar Matematika Siswa Kelas VII SMP Negeri 11 Maros Baru setelah penerapan model Pembelajaran Kooperatif Tipe Number Head Together (NHT) memperoleh nilai rata-rata 80.30 dan standar deviasi 8.354. Sedangkan hasil Belajar Matematika Siswa Kelas VII SMP Negeri 11 Maros Baru setelah penerapan model Pembelajaran Kooperatif Tipe Think Pair Share (TPS) memperoleh nilai rata-rata 71,50 dan standar deviasi 10.014. Ini berarti bahwa terdapat perbedaan rata-rata hasil belajar siswa setelah penerapan model pembelajaran kooperatif tipe Number Head Together (NHT) dan Think Pair Share (TPS) berbasis media whatsapp pada kelas VII SMP Negeri 11 Maros Baru. Ini dihitung dengan menggunakan SPSS 24 mada didapatkan nilai rata-rata pada kelas Eksperimen I (NHT) 80.30 sedangkan Nilai rata-rata pada Kelas Eksperimen II 71, 50 dan hipotesis juga menunjukkan bahwa nilai sig. (2-tailed) $0.047<0,05$ maka Ho ditolak atau terdapat pebedaan rata-rata siswa. Sehingga dapat terlihat adanya perbedaan nilai rata-rata yang diperoleh kelas Eksperimen I (NHT) dan Eksperimen II (TPS). Observasi keterlaksanaan model yang dilakukan selama penelitian berlangsung pada dua kelas yang berbeda terlaksana dengan baik dengan persentase $100 \%$. 


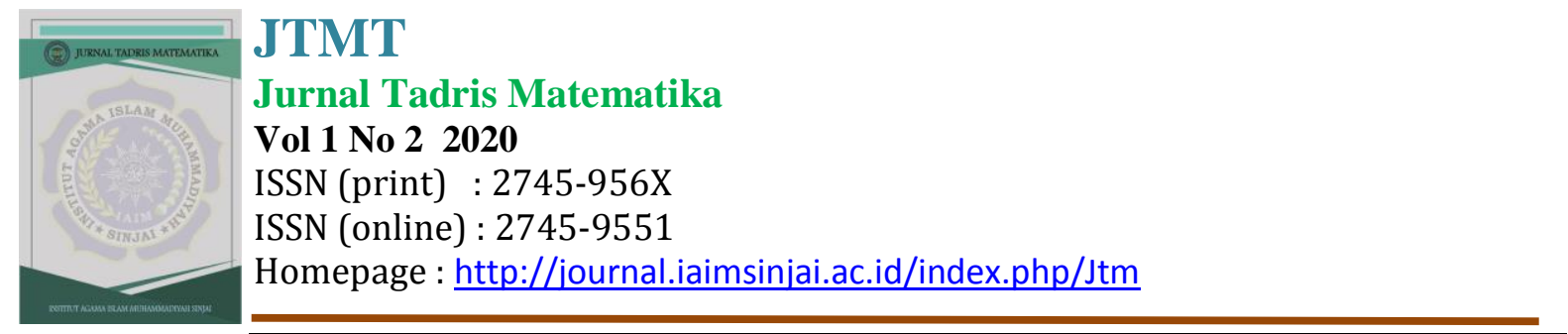

Daftar Pustaka

Ernawati, E., \& Lestari, P. I. (2020). Efektivitas Metode Problem Solving dengan Model Polya terhadap Hasil Belajar Peserta Didik dalam Menyelesaikan Soal Cerita Matematika. Equals, 3(1), 50-62. https://doi.org/10.46918/eq.v3i1.582

Gasali, A., \& Nasir, A. M. (2019). Efektivitas Model Pembelajaran Kooperatif dengan Pendekatan Saintifik pada Materi Fungsi Terhadap Prestasi Belajar Matematika. 1, 5.

Hariyanti. (2019). Pengaruh Pemberian Reward Terhadap Hasil Belajar Matematika pada Siswa Kelas VIII SMP DDI Maros.

Rahmayanti. (2017). Perbandingan Hasil Belajar Matematika Antara Siswa yang Diajar Dengan Menggunakan Model Pengajaran Langsung dan Discovery Learning pada Siwa Kelas VII SMP Negeri 1 Wonomulyo. http://eprints.unm.ac.id/id/eprint/6299

Rohani, Siti. (2015). Perbedaan Hasil Belajar Matematika Siswa Antara Yang Menggunakan Model Pembelajaran Kooperatif Tipe Numbered Heads Together (NHT) Dengan Tipe Think Pair Share (Tps) Di Kelas X Mia Sma Negeri 1 Sojol. 04(01), 24-31.

Rohani, Sitti. (2017). Perbedaan Hasil Belajar Matematika Siswa Antara Yang Menggunakan Model Pembelajaran Kooperatif Tipe Numbered Heads Together (NHT) Dengan Tipe Think Pair Share (Tps) Di Kelas X Mia Sma Negeri 1 Sojol. 8.

Susilo. (2013). Metode Penelitian Bidang Pendidikan: Kuantitatif, Kualitatif, dan Campuran.

Syarifuddin. (2020). Efektivitas Penerapan Model Learning Cycleterhadap Pemahaman Konsep Matematika Materi Teorema Pythagoras Siswa Kelas VIII SMP Negeri 3 Salomekko Kabupaten Bone. https://doi.org/10.47435/jtm.v1i1.394 